Kurtides, E. S., Rambach, W. A., Alt, H. L., and Del Greco, F. (1964). fournal of Laboratory and Clinical Medicine, 63, 469.

Lajtha, L. G. (1961). The Use of Isotopes in Haematology. Oxford, Blackwell Scientific Publications.

Lawson, D. H., Will, G., Boddy, K., and Linton, A. L. (1969). In Dialysis and Renal Transplantation: Proceedings of the 5 th ConDerence of the European Dialysis and Transplant Association, edited
forition by D. N. S. Kerr, p. 167. Amsterdam, Excerpta Medica.

MacKenzie, J. C., Ford, J. E., Waters, A. H., Harding, N., Cattell, W. R., and Anderson, B. B. (1969). In Dialysis and Renal Transplantation: Proceedings of the 5th Conference of the European Dialysis and Transplant Association, edited by D. N. S. Kerr, p. 172. Amsterdam, Excerpta Medica.
Mann, D. L., Donati, R. M., and Gallagher, N. I. (1965). Fournal of the American Medical Association, 194, 1321

Maynard, L. S., and Fink, S. (1956). Journal of Clinical Investigation, $35,831$.

Mirand, E. A., Murphy, G. P., Steeves, R. A., Weber, H. W., and Retief, F. P. (1968). Acta Haematologica, 39, 359

Tudhope, G. R., and Wilson, G. M. (1956). British fournal of Haemato$\log y, 2,75$.

Wright, F. K., Goldsmith, H. J., and Hall, S. M. (1969). In Dialysis and Renal Transplantation:" Proceedings of the 5 th Conference of the European Dialysis and Transplant Association, edited by D. N. S. Kerr, p. 179. Amsterdam, Excerpta Medica.

Yalow, R. S., and Berson, S. A. (1951). Science, 114, 14.

\title{
Neurological Disease after Partial Gastrectomy
}

\author{
J. ALEXANDER WILliAMS, *\| CH.M., F.R.c.s. ; G. S. HALL, † M.D., F.R.C.P. ; A. G. THOMPSON, $\ddagger$ M.B., CH.B. \\ W. T. COOKE,§ M.D., F.R.C.P.
}

British Medical fournal, 1969, 3, 210-212

Summary : Clinical and laboratory signs of neurological disease were found in 14 patients many years after partial gastrectomy. Vitamin $B_{12}$ deficiency occurred in most patients, but only those three who had signs of subacute combined degeneration of the cord and no osteomalacia responded well to treatment.

\section{Introduction}

There have been relatively few reports of serious neurological disease as a complication of partial gastrectomy. The first description of "subacute combined degeneration of the cord" following a Billroth II partial gastrectomy was recorded by

* Consultant Surgeon.

+ Formerly Consultant Neurologist.

$\neq$ Formerly House-surgeon.

The General Hospital, Birmingham 4.

II In receipt of a grant from the Medical Research Council.
Knox and Delamore (1960), and since then there have been fewer than 10 other cases reported. Nevertheless, Olivarious and Roos (1965) suggested that such neurological complications are much more common; from a variety of Scandinavian sources they were able to review 26 cases of "myelopathy" associated with low serum vitamin- $B_{12}$ levels after gastrectomy. In these patients the average time of onset of neurological symptoms was more than 10 years after operation.

\section{Present Series}

In a five-year period in our centre we have seen and treated 14 patients with neurological disease after partial gastrectomy. In many of these the response to treatment has been poor and some are permanently incapacitated with an irreversible neurological disorder. (Although relatively rare this is obviously an important clinical problem.) The findings in these patients are summarized in Table $\mathrm{I}$.

\begin{tabular}{|c|c|c|c|c|c|c|c|c|c|c|c|c|c|c|c|c|c|}
\hline & & Case & No.: & 1 & 2 & 3 & 4 & 5 & 6 & 7 & 8 & 9 & 10 & 11 & 12 & 13 & 14 \\
\hline $\begin{array}{l}\text { Sex } \\
\text { Age (years) } \\
\text { Ulcer site ... } \\
\text { Operation } \\
\text { Time interval (year }\end{array}$ & $\begin{array}{c}\ddot{ } \\
\ddot{0} \\
\text { ars) }\end{array}$ & $\begin{array}{l}\ddot{ } \\
\ddot{0} \\
\ddot{.}\end{array}$ & $\begin{array}{l}. \\
\because \\
\because \\
.\end{array}$ & $\begin{array}{l}\text { F } \\
51 \\
\text { G } \\
\text { BII } \\
14\end{array}$ & $\begin{array}{l}M \\
55 \\
D \\
\text { BII } \\
5\end{array}$ & $\begin{array}{l}\text { M } \\
50 \\
D \\
\text { BII } \\
5\end{array}$ & $\begin{array}{l}\text { M } \\
57 \\
\text { G } \\
\text { BII } \\
12\end{array}$ & $\begin{array}{l}M \\
56 \\
D \\
\text { BII } \\
16\end{array}$ & $\begin{array}{l}M \\
63 \\
\mathrm{G} \\
\mathrm{BII} \\
10\end{array}$ & $\begin{array}{l}M \\
63 \\
\text { G } \\
\text { BII } \\
10\end{array}$ & $\begin{array}{l}\mathrm{F} \\
68 \\
\mathrm{G} \\
\mathrm{BI} \\
12\end{array}$ & $\begin{array}{l}M \\
68 \\
\text { G } \\
\text { BII } \\
14\end{array}$ & $\begin{array}{l}F \\
76 \\
G \\
\text { G.E. } \\
37\end{array}$ & $\begin{array}{l}\text { F } \\
54 \\
\text { G } \\
\text { BII } \\
11\end{array}$ & $\begin{array}{l}M \\
67 \\
\text { D } \\
\text { BII } \\
12\end{array}$ & $\begin{array}{l}M \\
41 \\
G \\
\text { BII } \\
14\end{array}$ & $\begin{array}{l}\mathrm{M} \\
55 \\
\mathrm{D} \\
\mathrm{BII} \\
13\end{array}$ \\
\hline $\begin{array}{l}\text { Symptoms: } \\
\text { Unsteadiness } \\
\text { Weakness } \\
\text { Paraesthesia } \\
\text { Numbness } \\
\text { Depression or ps } \\
\text { Loss of consciou }\end{array}$ & $\begin{array}{l}. . \\
\because \\
\because \\
\text { psychos } \\
\text { usness }\end{array}$ & $\begin{array}{c}. . \\
\ddot{0} \\
\text { sis } \\
. .\end{array}$ & $\begin{array}{l}\because \\
\because \\
\because \\
\therefore\end{array}$ & $\begin{array}{l}+ \\
+ \\
+ \\
+ \\
+ \\
+\end{array}$ & $\begin{array}{l}+ \\
+ \\
+ \\
+ \\
+\end{array}$ & $\begin{array}{l}+ \\
+ \\
+ \\
+ \\
+ \\
+\end{array}$ & $\begin{array}{l}+ \\
+ \\
+ \\
+ \\
+\end{array}$ & $\begin{array}{l}+ \\
+ \\
+ \\
+ \\
+ \\
-\end{array}$ & $\begin{array}{l}+ \\
+ \\
+ \\
+ \\
+\end{array}$ & $\begin{array}{l}+ \\
+ \\
+ \\
+\end{array}$ & $\begin{array}{l}+ \\
+ \\
+ \\
+ \\
+\end{array}$ & $\begin{array}{l}+ \\
+ \\
+ \\
- \\
+\end{array}$ & $\begin{array}{l}+ \\
+ \\
+ \\
+ \\
+\end{array}$ & $\begin{array}{l}+ \\
+ \\
+ \\
+ \\
+\end{array}$ & $\begin{array}{l} \pm \\
\pm \\
\pm \\
\pm \\
-\end{array}$ & $\begin{array}{l}+ \\
+ \\
+ \\
- \\
-\end{array}$ & $\begin{array}{l}+ \\
\pm \\
+ \\
+\end{array}$ \\
\hline $\begin{array}{l}\text { Signs: } \\
\text { Wasting in legs } \\
\text { Hypotonia } \\
\text { Plantar response } \\
\text { Loss of position } \\
\text { Loss of vibratior } \\
\text { Loss of pin-pricl }\end{array}$ & $\begin{array}{l}\text { e } \\
\text { n sense } \\
\text { on sens } \\
\text { ck sens }\end{array}$ & $\begin{array}{l}. . \\
\because \\
\text { se } \\
\text { sation }\end{array}$ & $\begin{array}{l}. \\
\because \\
\cdots \\
\cdots\end{array}$ & $\begin{array}{l}- \\
\overline{\text { Fl }} \\
+ \\
+ \\
\pm\end{array}$ & $\begin{array}{l} \pm \\
\\
\text { Ex } \\
+ \\
+ \\
+\end{array}$ & $\begin{array}{l}+ \\
+ \\
+ \\
\text { Ex } \\
+ \\
+ \\
+\end{array}$ & $\begin{array}{l}+ \\
+ \\
+ \\
\text { Fl } \\
+ \\
+\end{array}$ & $\begin{array}{l}+ \\
+ \\
\text { F1 } \\
+ \\
+ \\
+\end{array}$ & $\begin{array}{l} \pm \\
\text { Ex } \\
+ \\
+ \\
+\end{array}$ & $\begin{array}{l}+ \\
+ \\
\text { Ex } \\
+ \\
\pm\end{array}$ & $\begin{array}{l} \pm \\
\pm \\
\mathrm{F} 1 \\
+ \\
\pm \\
-\end{array}$ & $\begin{array}{l}+ \\
+ \\
\text { F1 } \\
+ \\
+ \\
-\end{array}$ & $\begin{array}{l}+ \\
+ \\
\text { F1 } \\
+ \\
+ \\
+\end{array}$ & $\begin{array}{l}- \\
\overline{\mathrm{F}} 1 \\
\overline{+} \\
\pm\end{array}$ & $\begin{array}{l}- \\
\overline{\text { Ex }} \\
+ \\
\pm \\
\pm\end{array}$ & $\begin{array}{l}- \\
+ \\
\text { Ex } \\
+ \\
+ \\
+\end{array}$ & $\begin{array}{l}+ \\
+ \\
\text { Fl } \\
+ \\
+ \\
+\end{array}$ \\
\hline 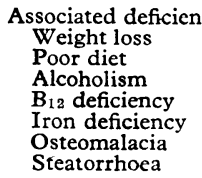 & $\begin{array}{l}\text { ncies: } \\
\because \\
\because \\
\because \\
\because \\
\because \\
\because\end{array}$ & $\begin{array}{l}\because: \\
\because \\
\because \\
\because \\
.\end{array}$ & $\begin{array}{l}\because \\
\because \\
\because \\
\because\end{array}$ & $\begin{array}{l}+ \\
\pm \\
+ \\
+ \\
+ \\
+\end{array}$ & $\begin{array}{l}+ \\
\pm \\
+ \\
\pm \\
+\end{array}$ & $\begin{array}{l}- \\
+ \\
+ \\
+ \\
+ \\
+\end{array}$ & $\begin{array}{l}+ \\
\pm \\
\overline{+} \\
+ \\
+ \\
+\end{array}$ & $\begin{array}{l} \pm \\
\overline{+} \\
\pm \\
+\end{array}$ & $\begin{array}{l} \pm \\
\bar{t} \\
+ \\
+\end{array}$ & $\begin{array}{l} \pm \\
\pm \\
\pm \\
\pm \\
+\end{array}$ & $\begin{array}{l}\overline{ \pm} \\
\pm \\
\pm \\
\pm\end{array}$ & $\begin{array}{l}+ \\
+ \\
+ \\
+ \\
+ \\
+\end{array}$ & $\begin{array}{l}+ \\
+ \\
+ \\
+ \\
+ \\
+\end{array}$ & $\begin{array}{l}+ \\
+ \\
+ \\
+ \\
+\end{array}$ & $\begin{array}{l}\overline{-} \\
\overline{+} \\
+ \\
+ \\
+ \\
+\end{array}$ & $\begin{array}{l}+ \\
+ \\
+ \\
+ \\
+ \\
+\end{array}$ & $\begin{array}{l}+ \\
+ \\
+ \\
+ \\
+ \\
+ \\
+\end{array}$ \\
\hline
\end{tabular}


Table II.-Evidence of Vitamin $B_{12}$ Deficiency

\begin{tabular}{|c|c|c|c|c|c|c|c|c|c|c|c|c|c|c|}
\hline Case No.: & 1 & 2 & 3 & 4 & 5 & 6 & 7 & 8 & 9 & 10 & 11 & 12 & 13 & 14 \\
\hline $\begin{array}{c}\text { Serum } \mathbf{B}_{12} \text { levels } \mu \mu \mathrm{g} . / \mathrm{ml} \text {. on } \\
\text { first presentation } . . \\
\text { Vitamin-B } B_{12} \text { absorption tests } \\
\text { (counts } / \mu \mathrm{Ci} / \text { sec., by the surface } \\
\text { hepatic counting method of } \\
\text { Glass et al. (1954)): } \\
\text { Without intrinsic factor } \\
\text { With intrinsic factor }\end{array}$ & $\begin{array}{l}1,271 \\
1,659\end{array}$ & $\begin{array}{r}724 \\
1,234\end{array}$ & $283^{*}$ & $\begin{array}{l}1,390 \\
4,500\end{array}$ & 二 & $\begin{array}{r}426 \\
4,646\end{array}$ & $=$ & 二 & $\begin{array}{l}455 \\
517\end{array}$ & 二 & $\begin{array}{l}1,093 \\
1,920\end{array}$ & $\begin{array}{r}755 \\
2,740\end{array}$ & $\stackrel{0}{0}$ Over 1,500 & $=$ \\
\hline
\end{tabular}

Neurological Presentation.-All patients complained of difficulty on walking, with unsteadiness and muscular weakness. The majority also had paraesthesia or numbness and a feeling of malaise or depression. Attacks of loss of consciousness were reported by five. All patients had abnormal neurological signs in a lower limb and all had muscle weakness; in 10 cases gross muscle-wasting occurred. Loss of vibration sense below the costal margin was also a universal finding, and loss of proprioception occurred in 11 with rombergism in 10. Furthermore, unequivocal evidence of abnormal neurological signs in an upper limb was present in only four patients (Cases 3, 6, 12, and 13). These signs included diminished pin-prick sensation in two, loss of two-point discrimination also in two, muscle weakness of the upper limbs in four, and ataxia in three.

Peripheral Nerve Abnormalities.-In seven of these patients electromyography and nerve conduction tests were normal. In skeletal muscle biopsy specimens, however, vital staining with methylene blue showed abnormalities of the terminal motor innervation in all seven patients examined. Histochemical and electron microscopical examinations are being made and will be the subject of a future report (A. L. Woolf, personal communication, 1967). The microscopical abnormalities of the terminal motor innervation are similar to those seen in nutritional neuropathy in adult coeliac disease (sprue syndrome) (Cooke, Johnson, and Woolf, 1966).

Associated Postgastrectomy Deficiencies.-Only one patient was seriously anaemic on presentation, though some had already been treated, and all those who had not been treated showed signs of iron deficiency. Serum levels of vitamin $B_{12}$ were below normal and there was evidence of vitamin- $B_{12}$ malabsorption in most patients, but this was not inevitable. Three patients had normal serum vitamin- $B_{12}$ levels, no macrocytosis, and normal radioactive vitamin- $\mathrm{B}_{12}$ absorption (Table II). Eight patients had osteomalacia, which was proved by bone biopsy or by biochemical response to vitamin-D therapy. Early in the series four patients were not specifically examined for osteomalacia. The serum folic acid level was measured in 10 patients ; in one patient it was $2.1 \mu \mathrm{g} . / \mathrm{ml}$., while all the rest had levels of above $3.7 \mu \mathrm{g} . / \mathrm{ml}$.

Aetiological Factors.-Ten males and four females were studied in the series; this is in keeping with the sex ratio of all postgastrectomy patients seen in our gastrectomy clinic. There was, however, a definite preponderance of patients whose original operation had been for gastric ulcer as compared with those with duodenal ulcer $(9: 5)$. One patient had had a gastrojejunostomy, while all the rest had had Billroth II operations; however, one of these (Case 14) had been converted to a Billroth I anastomosis two years before the onset of signs of neuropathy. A Wassermann test, which was performed on the serum of six patients and on the cerebrospinal fluid of two, proved negative in all. Eleven patients had lost weight and all but one had steatorrhoea. The amount of faecal fat excreted each day was, however, within the usual postgastrectomy (Billroth II) range of 7 to $10 \mathrm{~g}$. In only one case was it above 12 g./day. Bacteriological examination of the upper jejunal contents in all six of those examined showed gross contamination (Table III). Biopsy specimens of the small bowel showed no villous abnormality in the six patients examined, while those of the stomach showed gastritis in three, gastric atrophy in two, and normal mucosa in one.
TABLE III.-Culture of fejunal Aspirate

\begin{tabular}{c|c|l}
\hline Case No. & Viable Count/ml. & \multicolumn{1}{|c}{ Organisms } \\
\cline { 1 - 3 } 1 & $20 \times 10^{9}$ & $\begin{array}{l}\text { E. coli. Ps. pyocyanea. Staph. aureus. Staph. } \\
\text { allus. Str. faecalis. Str. viridans }\end{array}$ \\
3 & $35 \times 10^{6}$ & E. coli. Str. faecalis. Klebs. aerogenes \\
4 & $10 \times 10^{7}$ & Klebs.aerogenes. Str. viridans \\
5 & $20 \times 10^{6}$ & E. coli \\
9 & E. coli. Proteus. Staph. albus \\
10 & E. coli. Candida \\
\hline
\end{tabular}

Response to Treatment.-There was dramatic improvement after vitamin- $\mathrm{B}_{12}$ therapy in three of the patients (Cases 2, 6, and 13) in whom there was gross vitamin- $B_{12}$ deficiency but no osteomalacia. The neurological signs in these patients were florid, with extensor plantar responses, rombergism, and anaesthesia. The remaining patients showed a variable but usually poor response to treatment. Some improved temporarily with vitamin $B_{12}$ and others responded partially to additional parenteral multivitamin preparations. Correction of the vitamin-D deficiency produced no dramatic neurological improvement in any patient but may have contributed to the slight improvement seen in some.

\section{Discussion}

Neurological abnormalities are known to be associated with a variety of gastrointestinal diseases including regional enteritis, intestinal blind-loop syndrome, primary amyloidosis, Whipple's disease, and adult coeliac disease (Cooke and Smith, 1966). They are also associated with carcinomatosis and alcoholism. In this series of patients all these possibilities have not been completely excluded. All the patients reported here, however, had one common feature, neurological symptoms presenting many years after partial gastrectomy. Though it cannot be proved that the partial gastrectomy caused the neuropathy we have attempted so far as is possible to exclude other causes.

In the six patients in whom primary small-bowel disease seemed a possible diagnosis jejunal biopsy showed no villous abnormality. In the remaining eight cases primary small-bowel disease cannot be excluded but is thought unlikely. Regional enteritis and jejunal diverticulosis can be excluded in all cases by means of barium studies of the small bowel. There is possibly a close relation between this postgastrectomy neurological disease and the intestinal blind-loop syndrome, particularly in view of the high number of Escherichia coli and other "colonic" organisms found on jejunal aspirations in the five patients examined. The effect of long-term antibiotic therapy has not yet been fully evaluated in these patients, but no striking improvement has been observed so far.

Psychopathic disturbances are a notable feature of most of these latter patients and many are difficult to treat as they will not attend for supervision.

The response to vitamin $\mathrm{B}_{12}$ appears to separate these patients into two overlapping groups. The three patients who had a good response to vitamin $B_{12}$ had more florid neurological disease with a typical picture of "subacute combined degeneration" while those with a poor response had more in common with the patients with neuropathy complicating adult cocliac disease as described by Cooke and Smith (1966). 
Osteomalacia should be suspected, particularly in the resistant cases. If detected it should be treated with vitamin D. Nevertheless, the dangers of vitamin-D overdose must be stressed and for this reason regular therapeutic doses of vitamin $\mathrm{D}$ should be given only with the safeguard of regular supervision.

\section{REFERENCES}

Cooke, W. T., Johnson, A. G., and Woolf, A. L. (1966). Brain, 89, 663. Cooke, W. T., and Smith, W. T. (1966). Brain, 89, 683.

Glass, G. B. J., Boyd, L. J., Gellin, G. A., and Stephanson, L. (1954). A

Knox, J. D. E., and Delamore, I. W. (1960). British Medical fournal, 2, 1494

Olivarious, B. de F., and Roos, D. (1965). Lancet, 2, 1298.

\title{
Urinary Concentrating Ability in Women with Asymptomatic Bacteriuria in Pregnancy
}

\author{
G. L. WILLIAMS,* M.B., B.CH., M.R.C.o.g.; H. CAMPBELL, $†$ M.A., M.B., F.S.S. ; K. J. DAVIES $\ddagger$
}

Summary : The incidence of impaired renal concentrat$N$ ing abitity in pregnant women with asymptomatic significant becteriuria is significantly less than previously reported when osmolality readings are performed on every urine specimen obtained during the 24 hours' deprivation of fuids. The concentrating defect is more considerable as pregnancy progresses. The lower the maximum urinary osmolality the more difficult is the treatment of the patient, and the higher the incidence of acute pyelonephritis.

\section{Introduction}

Kaitz (1961) showed that certain pregnant women with asymptomatic bacteriuria had impaired urinary concentrating ability, a finding confirmed by Norden and Tuttle (1965) and by Elder and Kass (1965). This paper further investigates the relationship of maximum urinary concentrating ability in pregnant women with bacteriuria to age, parity, period of gestation when the test is performed, osmolality readings throughout a 24-hour period of restricted fluids, and total 24-hour urinary volume. The subsequent development of symptomatic urinary tract infection is also studied.

Throughout this study significant bacteriuria is defined as the presence of more than 100,000 Gram-negative organisms per $\mathrm{ml}$. of urine in at least two consecutive specimens in any patient.

\section{Patients and Methods}

All pregnant women who attended for antenatal care in Cardiff in 1967 had a midstream urine specimen collected on their first visit. Preliminary vulval cleansing with a weak cetrimide solution (Williams et al., 1969) was first performed. Clean voided specimens were then returned to the laboratory in iced vacuum flasks.

Urino Culture.-Within two hours of collection dilutions of urine were spread on to the surface of blood agar and MacConkey's medium plates. Quantitative colony counts were made after overnight incubation at $37^{\circ} \mathrm{C}$. If the specimen contained more than 10,000 Gram-negative organisms per ml., a second specimen was examined within 10 days.

Of 5,542 patients $211(3.8 \%)$ were found to have asymptomatic significant bacteriuria. These 211 were told that a slight

\footnotetext{
* United Cardiff Hospitals, Research Fellow in Obstetrics and Gynaecology.

† Senior Lecturer, Department of Medical Statistics.

$¥$ Department of Medical Statistics.

Weloh National School of Medicine, Cardiff.
}

urinary tract infection might be present, and arrangements were made for their admission to the antenatal ward for a period of 24 hours within the next few days. Studies were completed on $163(77 \%)$ patients. The period of the test was from 12 noon on the first day to 12 noon on the second, during which period they refrained from all fluids, dry food only being allowed. They were not kept in bed, and were asked to pass urine three- to four-hourly. All the urine passed was collected and measured. Osmolality determinations were done on the Advanced Instruments Osmometer, the urine being left at $4^{\circ} \mathrm{C}$. until the measurement was performed within three hours of collection.

Similar investigations were performed on a group of pregnant women with sterile urine. One woman at each hospital booking clinic was asked if she would come into hospital for a period of 24 hours in order that her renal function could be estimated. It was explained to her that the test would entail deprivation of fluid for 24 hours. If she preferred not to do so, another was asked, and so on until a volunteer was found. In this way 45 normal controls were included in the study.

One of the major aims of this study was to determine the effects of treatment of asymptomatic bacteriuria in pregnancy, and a randomized controlled clinical trial was started as soon as the presence of bacteriuria had been established and the osmolality studies completed. The clinical trial will be reported elsewhere, but osmolality had an important effect on the outcome of treatment which is considered here.

Patients were allocated at random to "treatment" or "control" groups. The treatment group was prescribed a course of sulphadimidine $1 \mathrm{~g}$. three times a day for seven days, then two or three weeks after the end of this course the urine was re-examined. If it was sterile no further treatment was given, if it was not sterile the patient was prescribed $100 \mathrm{mg}$. of nitrofurantoin twice daily for seven days. If this was successful no further treatment was given, but if the bacteriuria still persisted ampicillin $250 \mathrm{mg}$. three times daily for seven days was prescribed ; if necessary this course of ampicillin was repeated. No patient in the treatment group received more than one course of sulphadimidine or of nitrofurantoin, but some required repeated courses of ampicillin. Those patients who relapsed after having sterile urine continued the pattern of these treatments at the point where it had been interrupted.

Patients allocated to the contrast group did not receive treatment for their asymptomatic bacteriuria until such time as symptoms presented. These women were, however, given a supply of sulphadimidine and told to take $1 \mathrm{~g}$. three times a day for seven days if they suffered from symptoms of frequency, 